\title{
Treatment of an impacted inverted tooth: A case report
}

\author{
Jae-Hwan Kim', Sang-Ho Lee ${ }^{2}$, Nan-Young Lee ${ }^{2}$, Myeongkwan Jih ${ }^{2 \star}$ \\ ${ }^{1}$ Department of Pediatric Dentistry, School of Dentistry, Chonnam National University, Gwangju, Korea \\ ${ }^{2}$ Department of Pediatric Dentistry, School of Dentistry, Chosun University, Gwangju, Korea
}

An impacted tooth may occur in horizontal, vertical, centripetal, or inverted form. The inverted form often occur in a mesiodens, but a permanent tooth may also take this form. Various treatments are available depending on the depth of the impaction, the space between the dental arch and the teeth, the relationship of the impacted tooth with the adjacent teeth, and potential future complications caused by the impaction. Typically, a tooth deviating from its normal position is an indication for extraction, unless it is supernumerary, it is often desirable to use a treatment method that preserves the impacted tooth. This case study described two successful cases involving pediatric patients at the Dental Hospital of Chosun University who were treated using surgical exposure and orthodontic traction.

Key Words: Impacted tooth, Inverted tooth, Traction

(c) This is an open-access article distributed under the terms of the Creative Commons Attribution Non-Commercial License (http://creativecommons.org/licenses/by-nc/4.0) which permits unrestricted noncommercial use, distribution, and reproduction in any medium, provided the original work is properly cited.

\section{서 론}

매복치란 병리학적 의미로는 맹출 시기가 지났음에도 불구하 고 치관이 맹출하지 않고 구강점막 또는 골내에 묻혀있는 치아 를 의미하지만, 임상적으로는 아직 맹출 시기가 되지 않았지만 치아의 형태, 위치, 방향, 맹출 공간 등을 고려할 때 맹출하지 않 을 것으로 예상되는 치아도 포함한다. 가장 흔하게 이환되는 치 아는 상·하악 제 3 대구치들이며, 하악 제 1 대구치의 매복은 비 교적 드문 편이다[1].

매복은 수평적, 수직적, 근심 경사, 원심 경사 또는 역위된 형 태로 발생할 수 있다[2]. 역위된 매복치의 경우 대부분 정중과잉 치에서 발생하지만 영구치에서 발생하는 경우도 종종 보고되고 있다[3].

역위된 매복치의 매복의 깊이, 악궁과 치아와의 공간, 주변 치 아와의 관계, 매복치가 향후 일으킬 수 있는 합병증 등을 판단하
여 여러 가지 치료 방법이 고려된다. 과거에는 맹출 경로가 정상 경로에서 많이 벗어난 치아들은 발치의 적응증으로 인식되어 왔으나 매복치아가 과잉치가 아닌 이상 최대한 보존적인 방법 을 통해 치료를 시행하는 것이 바람직하다고 생각한다.

이미 매복치가 역위된 상태로 존재한다면 일반적으로 맹출에 장애를 주는 물리적인 장애물 및 잔존 유치 발거 후 관찰로는 매 복치를 적절히 치료하기 어렵다. 최소한 외과적 노출 및 교정적 견인이 필요할 것이며 이 치료 방법이 최대한 보존적인 방법일 것이다. 외과적 노출 및 교정적 견인에 실패하거나 어렵다고 판 단된다면 매복치를 이식 또는 발거한 후 보철치료나 공간 폐쇄 를 시도하여야 한다.

본 연구에서는 역위된 형태로 매복된 치아를 주소로 조선대 학교 치과병원 소아치과에 내원한 환자를 외과적 노출 및 교정 적 견인을 시행하여 맹출을 유도한 두 가지 증례에 관하여 보고 하고자 한다.

Received January 22, 2019; Revised January 31, 2019; Accepted February 1, 2019

Corresponding author: Myeongkwan Jih, Department of Pediatric Dentistry, School of Dentistry, Chosun University, 309 Pilmun-daero, Donggu, Gwangju 61452, Korea.

Tel: +82-62-220-3868, Fax: +82-62-225-8240, E-mail: mdenti@chosun.ac.kr 


\section{증례보고}

\section{증례 1}

9세 남자 환아가 송곳니의 위치 이상으로 개인치과에서 조선 대학교 치과병원 소아치과에 의뢰되었다. 상악 좌측 유견치의 임시수복물은 파절되어 있었으며 방사선사진에서 치근단 방사 선 투과상이 관찰되었고 상방의 상악 좌측 견치는 역위 매복된 양상을 보였다(Fig. 1A). 상악 좌측 유견치는 임시수복물 상태로 보호자는 과거 치수치료를 받은 경험이 있음을 설명하였다. 상 악 좌측 견치 매복의 가장 큰 원인으로 판단되는 상악 좌측 유견 치를 발치한 후 공간유지장치 장착 하에 정기검진하기로 하였 다.

상악 좌측 유견치 발치 6개월 이후 방사선 투과상은 사라졌으 나 상악 좌측 견치의 위치 변화는 없어 교정적 견인치료를 시행 하기로 하였다. Cone-beam computed tomography (CBCT) 를 촬영했고(Fig. 1B), 환아의 협조도 및 치아의 위치를 고려했 을 때 수술의 어려움이 예상되어 전신마취 하에 외과적 노출술 을 시행하여 치관의 설면에 결찰 강선을 연결한 버튼(button)을 부착하였다(Fig. 2A). 이후 고리가 달린 가철성 장치와 결찰 강 선 사이에 교정용 악간 고무줄을 이용하여 치아 견인을 시행하 였다(Fig. $2 \mathrm{~B}$ ), 환아로 하여금 가철성 장치의 고리와 매복된 치
아에 부착된 설측 버튼의 결찰 강선 사이에 있는 교정용 고무줄 을 매일 교환하도록 교육하였다.

정기적인 임상검사가 매 1 개월마다 시행되었다. 장치 장착 10 개월 후 매복치의 치축의 개선과 바른 견인 방향을 위하여 매 복치의 외과적 노출 후 교정적 정출로 설측 버튼의 부착을 치관 협측부위에 시행하고 교정용 고무줄로 견인하였다.

매복치의 치관이 충분히 치은 밖으로 노출된 이후 브라켓을 직접 치관에 부착하는 direct bonding system을 이용하여 치아 의 배열을 시행하였다(Fig. 2C). 치료 시작 26개월 후 상악 좌측 견치는 적절한 위치에 배열되었고 치료를 종료하였다(Fig. 2D, 3). 치아의 동요도 검사 및 치수생활력 검사 결과도 정상이었다. 치아의 배열은 이상이 없으나 부착치은의 양이 부족하여 차후 치주수술을 계획하고 있다.

\section{증례 2}

8세 남자 환아가 상악중절치가 맹출되지 않는다는 주소로 개 인치과에서 조선대학교 치과병원 소아치과로 의뢰되었다. 개인 치과에서 작성된 의뢰서에는 상악 우측 유중절치 치수치료 이 후 염증 증상이 발생하여 치아를 발거하였다고 기술되어 있었 다. 방사선사진 촬영 결과 상악 우측 중절치는 만곡치의 모습을 보이며 치관은 상방을 향하여 있었다(Fig. $4 \mathrm{~A})$. 상악 우측 중절
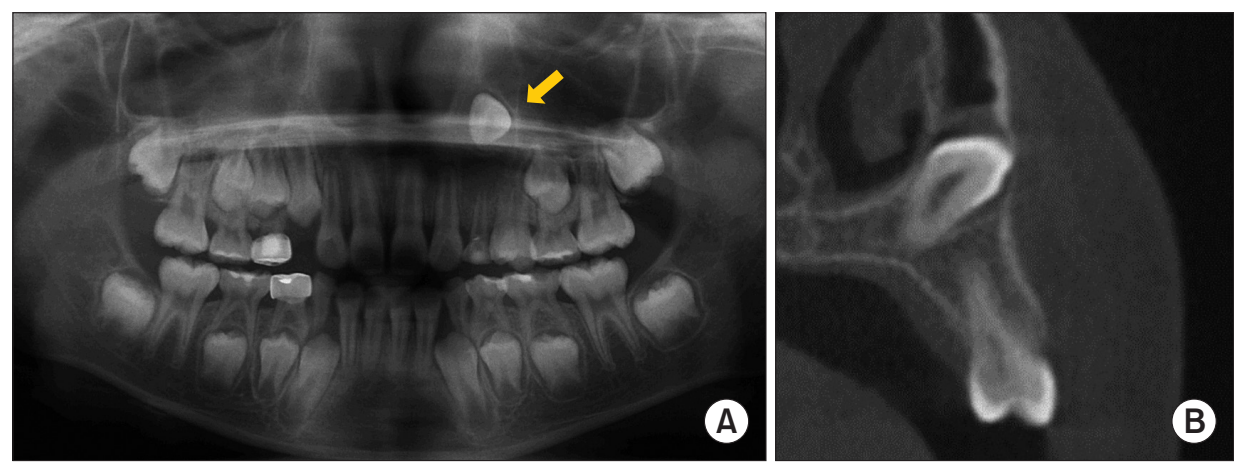

Fig. 1. (A) Initial panoramic view of case 1. Maxillary left canine inversion and a periapical lesion of the primary maxillary left canine were observed (arrow). (B) After 6 month, preoperative cone-beam computed tomography. The maxillary left canine remains inverted.
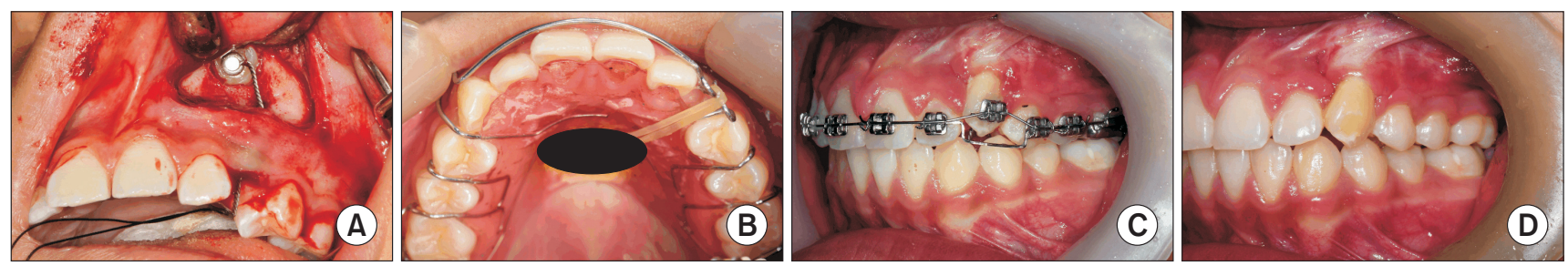

Fig. 2. Intraoral view of case 1. (A) Lingual button was attached to the lingual surface of the maxillary left canine's crown. (B) After 2 weeks, a removable appliance with a hook for traction was applied. (C) After the crown of the maxillary left canine was sufficiently exposed, a direct bonding system was used to perform the arrangement. An auxiliary NiTi wire was overlaid on the stabilizing arch wire. (D) After 26 months of treatment, the maxillary left canine reached the normal occlusal level. 
치의 상실로 상악 좌측 중절치와 상악 우측 측절치는 근심이동 하였으며 이로 인해 상악 우측 중절치의 맹출 공간이 상실되어 있었다. 정확한 매복치의 위치 및 주변 치아와의 관계 확인을 위 해 $\mathrm{CBCT}$ 를 촬영하였다(Fig. $4 \mathrm{~B}$ ).

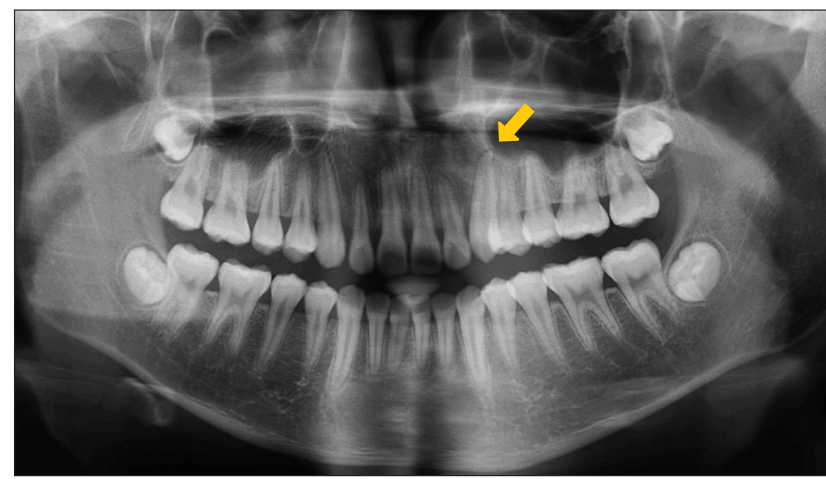

Fig. 3. Posttreatment panoramic view of case 1 . After 26 months of treatment, the maxillary left canine reached the normal occlusal level (arrow). The root of the tooth was slightly bent.
매복치 치근의 만곡으로 인한 상악 우측 중절치의 교정적 견 인 치료의 실패 가능성에 대해 충분히 설명하였고 보호자는 성 공 가능성이 낮아도 보존적인 치료를 시도해보고 싶어하였다. 매복치의 교정적 견인 실패 이후 발거 가능성 및 공간유지장치 장착에 대해서도 미리 설명한 후 치료를 시작하였다.

상악 우측 중절치를 견인하기에 앞서 공간을 확보하기 위해 서 능동적 교정장치(active plate)를 장착하고 핑거 스프링(finger spring)을 활성화시켜 공간을 확보하였다. 상악 우측 중절치 의 맹출 공간이 확보된 후 외과적 노출을 시행하여 치관의 설면 에 버튼을 부착하였다. 이후 교정용 악간 고무줄을 이용하여 견 인을 시작하였다. 이후 약 9개월 동안 교정적 견인을 진행한 후 치아의 경사를 고려하여 버튼을 협측으로 재부착한 뒤 다시 교 정적 견인을 진행하였다. 버튼의 위치를 변경한 뒤 6개월 후 매 복치가 치은 밖으로 맹출하였으며 처음 교정적 견인을 시작한 지 15 개월 후에 치아의 배열을 위하여 direct bonding system 으로 상악 치아에 브라켓 부착 후 치아의 배열을 시작하였다 (Fig. 5A, B). 치아의 맹출이 완료된 후 탄성 고무 사슬을 이용하 여 상악 전치부 치간공간을 폐쇄하였다(Fig. 5C). 치료를 시작한
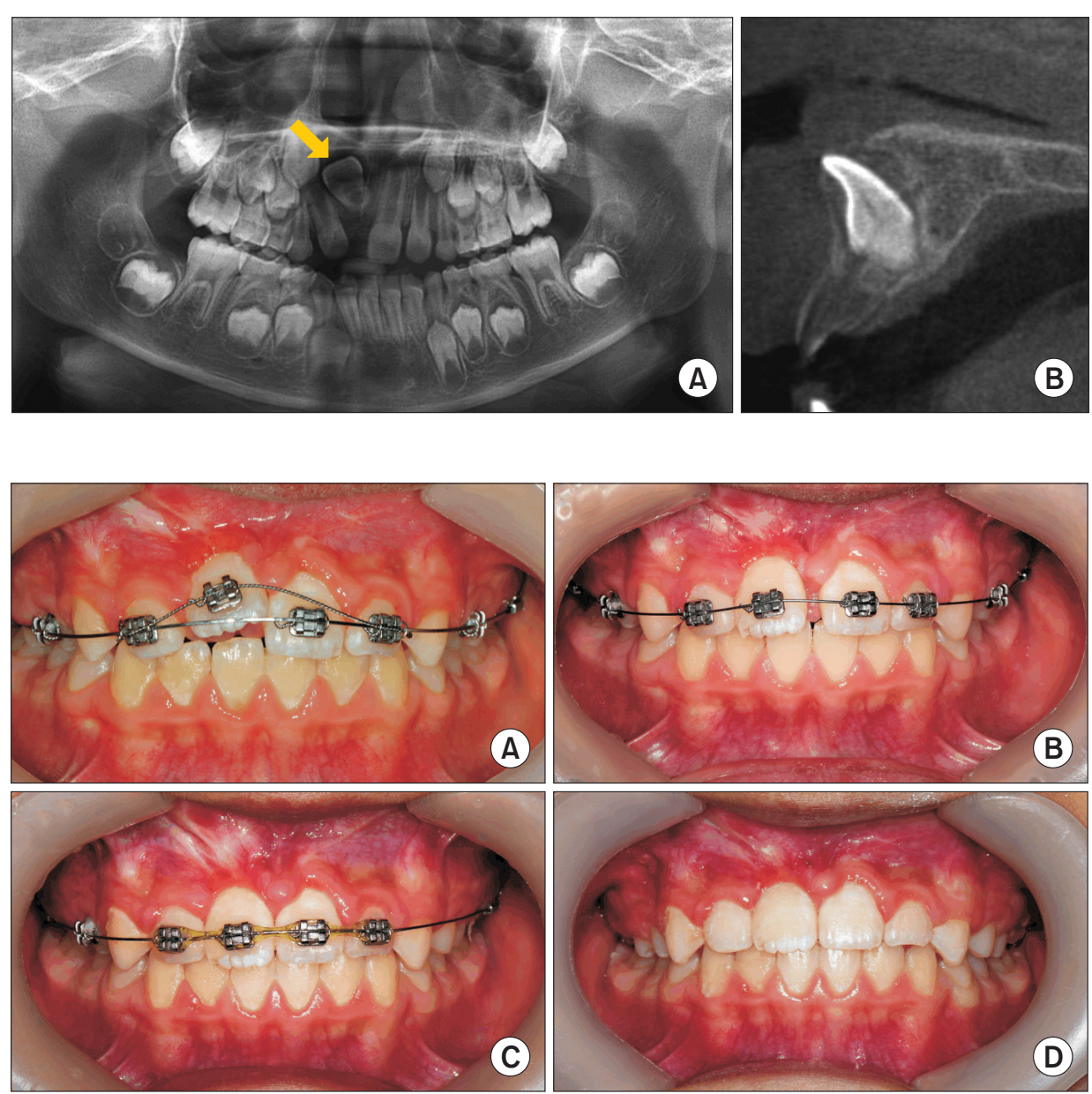

Fig. 4. (A) Initial panoramic view of case 2. Maxillary right incisor inversion and mesial movement of the maxillary left incisor and the maxillary right lateral incisor were observed (arrow). (B) Cone-beam computed tomography view.
Fig. 5. Intraoral view of case 2. (A) An auxiliary multistranded steel wire was overlaid on the stabilizing arch wire. (B) The maxillary right central incisor reached the normal occlusal level. (C) An elastic chain was used to close the intermaxillary incisor space. (D) After 24 months of treatment, all devices were removed. 


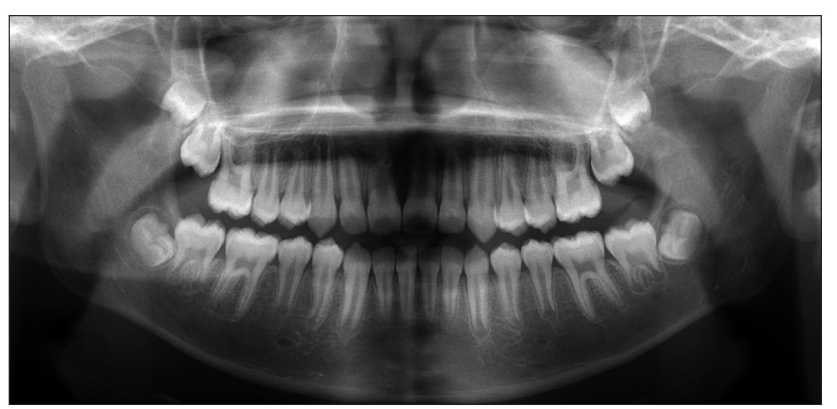

Fig. 6. Posttreatment panoramic view of case 2. Twenty-fourth months later, the treatment was finished. The root of the maxillary right central incisor was bent.

지 24개월 만에 모든 장치는 제거되고 역위된 매복치의 교정적 견인 치료를 마무리하였다(Fig. 5D, 6). 치아의 배열은 마무리 되었으며 부착치은의 양이 부족하여 차후 치주수술을 계획하고 있다.

\section{고 찰}

매복된 치아를 교정적 견인을 시도하여 치료하는 데에 있어 중요한 세 가지 범주는 외과적 노출 방법, 부착 방법, 그리고 미 맹출 치아에 가해지는 교정력을 적용하는 방법이다. 외과적 노 출 이후에 치관 부위를 덮지 않고 노출시킨 상태에서 치아를 견 인하는 개방술(open technique)은 외과적으로 치아를 노출시 키고 교정장치를 부착한 후 다시 덮어주는 폐쇄술(closed technique)에 비해 치조골의 상실 및 부착치은의 폭경이 감소할 위 험성이 크기 때문에 가능하면 폐쇄술을 사용하였다. 부착 방법 으로 치아에 브라켓을 바로 적용하지 않고 부피가 작아 적용하 고 제거하기 쉬운 버튼을 복합 레진을 이용하여 직접 부착하였 다. 마지막으로 매복치아의 교정력은 치아가 치은 밖으로 맹출 하여 적절히 브라켓을 적용할 수 있을 때까지는 가철성 장치와 고무줄을 이용하여 견인력을 부여하였고 이후 치아의 적절한 배열을 위하여 direct bonding system으로 상악 모든 치아에 브라켓을 부착하였다.

역위 매복된 치아의 외과적 개입은 다른 유형의 매복치보다 더 복잡한데 이는 치관의 비정상적인 위치 때문이다. 뼈의 삭제 량이 많고 신경 손상의 가능성이 높아 치관까지의 접근이 다른 형태의 매복치에 비해서 어렵다. 역위된 매복치의 치관에 버튼 을 부착할 때 가능하면 협면에 부착하는 것이 견인 시 힘의 방향 을 고려했을 때 바람직하겠지만 위 증례들의 경우 $\mathrm{CBCT}$ 촬영 검사로 매복치의 위치를 봤을 때 협면에 버튼을 부착하기에 많 은 골삭제 및 접근의 어려움으로 수술의 위험성이 높아진다고 판단하였다. 따라서 어느 정도 치아의 경사도와 위치가 개선된
이후에 협면에 버튼을 부착하는 시술을 한번 더 진행하여 수술 의 위험성을 최소화하려고 노력하였다.

첫 번째 증례에서는 교정적 견인을 시작한지 10 개월 뒤, 두 번째 증례에서는 9개월 뒤에 두 번째 외과적 노출술을 시행하여 매복치의 치관 협측 부위에 교정용 버튼의 부착을 시행하였다. 외과적 노출술을 두 번 시행한 이유는 설측에 부착된 교정용 버 튼만을 이용한 견인으로는 힘의 방향이 매복치를 정상적 위치 까지 견인하기에 바람직하지 못하기 때문이었다.

두 증례 모두 치관에 브라켓을 부착할 수 있을 정도로 매복 치가 치은 밖으로 견인된 이후 direct bonding system을 이용 하여 매복치를 배열하였다. 초기 배열과 레벨링 단계에서 치아 를 가장 효과적이고 효율적으로 움직이기 위해는 작고 지속적 인 힘이 가해지는 것이 필요하다. 그렇기 때문에 이상적인 초기 교정 와이어는 매우 유연해야 하고 최소의 변형을 보여야 한다 [4]. Multistranded stainless steel 와이어와 Niti 와이어는 이러 한 요구 조건들을 충족시킬 수 있다고 알려져 있다[5,6]. Multistranded stainless steel 와이어는 탄력성의 영향 없이 3 개의 가 는 와이어를 꼬아 강성을 보강시킨 와이어로 불규칙한 표면으 로 인해서 마찰력이 생긴다는 의견도 있지만 임상적으로 큰 문 제는 없는 것으로 알려져 있다.

일반적으로 교정치료를 시행할 때 치아의 악궁마다 모든 치 아를 하나의 와이어로 연결하는 배열 방법이 일반적이다. 그러 나 매복치는 인접치아에 비해 상-하방으로 변위가 심한 상태 로 direct bonding system을 이용하여 배열을 시도할 때, 안정 화된 와이어 상방에 부가적인 와이어를 위치시키는 오버레이 (overlay) 방법을 적용하는 것이 바람직하다[7]. 이는 매복치에 가해지는 과도한 힘을 방지할 수 있으며 주변 치아들이 매복치 방향쪽으로 쓰러져 치열궁 형태가 상실되는 현상을 방지할 수 있다. 부가적인 호선을 사용하는 것은 필요한 부위에만 탄성을 부여하고 그 이외 부위는 견고하게 악궁 형태를 유지하게 해준 다. 이는 특히 치조골이 소실되고 치주조직이 좋지 않은 성인에 게 사용하기에 좋은 방법이지만 매복치를 갖고 있는 소아·청소 년에서도 사용하기 좋은 술식이다. 위 증례들에서 연속된 초탄 성 와이어를 매복치를 포함하여 상악 모든 치아에 적용한다면 매복치가 견인되는 동시에 인접한 치아들이 매복치 쪽으로 경 사지게 될 것이다. 따라서 두 증례 모두 초기 배열 단계에서 매 복치를 제외한 나머지 치아를 먼저 배열한 이후에 이 치아들을 연결한 안정화된 와이어에 부가적인 와이어를 적용한 오버레이 방법을 사용하였으며 보다 안정적으로 매복치를 배열할 수 있 었다(Fig. 2C, 5A).

매복치의 원인은 아주 다양하다. 현재까지 과잉치나 낭종 등 의 물리적 장애, 영구치 치관 완성시기에 외상성 충격, 전신질 환, 그리고 유치의 감염 등이 보고되었다[8-10]. 
유치 치근단 병소는 계승 영구치의 변위 및 맹출 이상에 직접 영향을 미치는 것으로 알려져 있다[11,12]. 2가지 증례 모두 매 복된 치아의 이전 유치에서 치근단 염증이 있었던 것으로 추정 된다. 이 매복치들이 역위로 변위된 것은 매복치 상방에 위치하 는 유치의 치근단 염증에서 기인한 것으로 생각한다. 유치 치근 단 감염이 치료되지 않고 방치된 시간이 길수록 계승 영구치에 주는 영향은 크다고 알려져 있으므로 유치의 치수치료 후에도 치근단 감염이 발생한다면 치아의 빠른 발거가 더 큰 문제를 예 방할 수 있을 것이다. 두 가지 증례 모두 이른 시기에 발견되어 유치가 적절한 시기에 발치되었다면 치아의 심한 역위 매복은 일어나지 않았을 가능성이 높다고 생각한다.

따라서 치과의사들은 치근단 감염이 발생한 유치를 조기에 발견하여 치수치료 또는 발치를 시행해야 하며 만약 치수치료 를 시행한 치아가 치근단 감염이 발생하였다면 빠른 발치를 해 야 계승치에 미치는 영향을 최소로 할 수 있을 것이다.

외과적 노출 및 교정적 견인 치료가 모두 끝난 두 증례 모두 매복치의 생활력의 상실은 없었으며 특별한 임상적인 증상은 없었지만 몇몇 개선해야 할 문제점들이 있었다.

첫 번째 증례에서 배열이 끝난 매복치의 치아의 색을 주변 치 아들과 비교해보면 치관이 저광화된 양상의 변색을 보여주고 있음을 확실히 인지할 수 있었다. Bauer [13]와 Messer 등[14] 은 유치의 치수감염에 의하여 계승 영구치의 저석회화 양상이 관찰될 수 있다고 보고하였다. 배열이 끝난 변색 매복치를 갖 고 있는 환자들 중 특히 외모에 관심이 많은 청소년의 경우 치아 미백치료를 요구할 수 있다. 하지만 미성숙 영구치에서 carbamide peroxide 같은 미백제를 사용하는 것은 치수의 큰 사이 즈 및 민감성 때문에 되도록 피하는 것이 추천된다. 따라서 치과 의사는 환자의 미백치료를 청소년기 이후에 시행하는 것이 바 람직함을 환자와 보호자에게 잘 설명해 주어야 한다[15].

두 번째 문제점은 좋지 않은 예후의 치은이다. Vanarsdall과 Corn [16]은 매복치아를 치료할 때 치은 퇴축이 발생할 수 있으 며 부착치은의 상실을 보인다고 하였다. 본 논문의 두 증례들 모 두 치아의 배열은 교정치료로 문제 없이 마무리되었지만 치주 적인 부분에서 문제가 있었는데 바로 부착치은이 부족하다는 점이었다. Ryu 등[17]은 매복치의 맹출을 유도할 때 근단변위판 막술을 시행하여 오히려 인접치아보다 더 많은 양의 부착치은 을 확보한 것을 보고하였다. 이는 매복치를 견인하는 과정에서 근단변위판막술을 시행한 것으로 오히려 비심미적인 결과를 초 래할 수 있다고 하였다. 따라서 매복치의 배열 이후 부착치은을 증가시키는 치주 수술을 시행해주는 것이 심미적으로 더 큰 장 점이 있을 것으로 생각한다.

역위된 매복치의 맹출 경로가 정상 경로에서 많이 벗어났을 지라도 최대한 보존적인 방법을 통해 치료를 시행해야 하며 자
발적인 맹출을 기대하기 어렵기 때문에 외과적 노출술 및 교정 적 견인을 첫 번째로 고려하는 것이 바람직하다. 역위된 매복치 의 경우 매복된 위치 및 치관의 방향 때문에 외과적 수술과 교정 적 견인 모두 일반적인 정방향의 매복치의 치료보다 술자의 세 심한 노력이 필요할 것이다.

\section{ACKNOWLEDGEMENTS}

This study was supported by research fund from Chosun University Dental Hospital, 2017.

\section{CONFLICTS OF INTEREST}

The authors declare that they have no competing interests.

\section{ORCID}

\author{
Jae-Hwan Kim \\ https://orcid.org/0000-0001-8088-6216 \\ Sang-Ho Lee \\ https://orcid.org/0000-0003-2513-6871 \\ Nan-Young Lee \\ https://orcid.org/0000-0002-4738-9389 \\ Myeongkwan Jih \\ https://orcid.org/0000-0001-9579-076X
}

\section{REFERENCES}

1. Korean Academy of Pediatric Dentistry. Textbook of pediatric dentistry. 4th ed. Seoul: Shinhung International Inc.; 2007;566.

2. Msagati F, Simon EN, Owibingire S. Pattern of occurrence and treatment of impacted teeth at the Muhimbili National Hospital, Dar es Salaam, Tanzania. BMC Oral Health 2013;13:37. doi: 10.1186/1472-6831-13-37.

3. Bae SM, Hung BQ, Lee YG, Kyung HM. Treatment of an impacted and inverted upper premolar. J Clin Orthod 2017;51:173-178.

4. Reitan K. Some factors determining the evaluation of forces in orthodontics. Am J Orthod 1957;43:32-45. doi: 10.1016/0002-9416(57)90114-8.

5. Sandhu SS, Shetty VS, Mogra S, Varghese J, Sandhu J, Sandhu JS. Efficiency, behavior, and clinical properties of superelastic NiTi versus multistranded stainless steel wires: a prospective clinical trial. Angle Orthod 2012;82:915-921. doi: 10.2319/100311-622.1.

6. Evans TJ, Durning P. Aligning archwires, the shape of 
things to come?--a fourth and fifth phase of force delivery. Br J Orthod 1996;23:269-275. doi: 10.1179/bjo.23.3.269.

7. Proffit WR, Fields HW, Sarver DM. Contemporary orthodontics. 5th ed. St. Louis: Elsevier Inc.; 2013;542-543.

8. Kim YH. Treatment of an unusually impacted permanent maxillary central incisor. J Am Dent Assoc 1964;69:596600. doi: 10.14219/jada.archive.1964.0349.

9. Cangialosi TJ. Management of a maxillary central incisor impacted by a supernumerary tooth. J Am Dent Assoc 1982;105:812-814. doi: 10.14219/jada.archive.1982.0476.

10. Montalvo-Polk A, Kittle PE. Impaction and malformation of a maxillary central incisor: sequelae of trauma. ASDC J Dent Child 1993;60:29-32.

11. McCormick J, Filostrat DJ. Injury to the teeth of succession by abscess of the temporary teeth. J Dent Child 1967;34:501-504.

12. Choi SA, Lee NY, Lee CS, Lee SH. Case report: the displacement of permanent tooth buds by periapical lesions of anterior primary teeth. J Korean Acad Pediatr Dent 2005;32:224-228.

13. Bauer WH. Effect of periapical processes of deciduous teeth on the buds of permanent teeth; pathological-clinical study. Am J Orthod Oral Surg 1946;32:232-241. doi: 10.1016/0096-6347(46)90015-4.

14. Messer LB, Cline JT, Korf NW. Long term effects of primary molar pulpotomies on succedaneous bicuspids. J Dent Res 1980;59:116-123. doi: 10.1177/00220345800590020201.

15. William V, Messer LB, Burrow MF. Molar incisor hypomineralization: review and recommendations for clinical management. Pediatr Dent 2006;28:224-232.

16. Vanarsdall RL, Corn H. Soft-tissue management of labially positioned unerupted teeth. Am J Orthod 1977;72:53-64. doi: 10.1016/0002-9416(77)90124-5.

17. Ryu HS, Kown H, Lee CS, Lee SH. Eruption guidance of impacted maxillary central incisor with apically positioned flap. J Korean Acad Pediatr Dent 2001;28:383-390. 